\title{
KAJIAN ISLAM KLASIK TERHADAP FAKTOR-FAKTOR RISIKO UNDERWRITING PADA ASURANSI JIWA SYARIAH DALAM MENGEMBANGKAN BAURAN PEMASARAN
}

\section{Basuki Achmad ${ }^{凶}$}

Sekolah Tinggi Ilmu Fikih (STIF) Syeikh Nawawi Tanara Serang Banten - Indonesia

\begin{abstract}
Abstrak
Penelitian ini bertujuan untuk mengetahui faktor-faktor risiko underwriting yang akan mempengaruhi pengambilan keputusan melanjutkan atau merubah kebijakan underwriting pada Asuransi Jiwa Syariah, Penelitian ini melihat sudut pandang lain dari teori asuransi konvensional dan data industri asuransi jiwa syariah, teori mengenai cara menyeleksi calon peserta asuransi yang dikenal dengan underwriting yang menilai usia, tempat tinggal dan beberapa faktor lainnya akan dikaji dengan menemukannya dalam beberapa buku-buku islam klasik.
\end{abstract}

Kata Kunci: underwriting, asuransi jiwa syariah, peserta asuransi

\begin{abstract}
This study aims to determine the underwriting risk factors that will influence the decision to continue or change the underwriting policy in Sharia Life Insurance. known for underwriting which assesses age, place of residence and several other factors will be studied by finding it in some classic Islamic books.
\end{abstract}

Keywords: underwriting, sharia life insurance, insurance participants

Copyright (c) 2021 Basuki Achmad.

$\square$ Corresponding author : Basuki Achmad

Email Address : basuki.achmad@gmail.com 


\section{PENDAHULUAN}

Berdasarkan data yang di rilis oleh Biro Pusat Statistik, disebutkan bahwa tahun 2017 Indonesia memiliki jumlah penduduk sebanyak 261.890.000 juta jiwa dengan angka harapan hidup laki-laki 2016 adalah 69,09 tahun dan angka harapan hidup perempuan 2016 adalah 72,80 tahun ${ }^{1}$. Sekitar $87 \%$ dari jumlah tersebut atau 227.844 .300 juta jiwa penduduk beragama Islam, sehingga berdasarkan fakta tersebut, maka wajar jika Indonesia dinobatkan sebagai Negara dengan mayoritas penduduk muslim terbesar didunia.

Klaim bahwa Indonesia merupakan Negara dengan penduduk beragama Islam terbesar didunia, seharusnya menjadi surga bagi industri keuangan syariah khususnya market asuransi syariah, namun faktanya tidak, market share asuransi syariah dibandingkan dengan asuransi konvensional dari segi kontribusi(premi) pada tahun 2012 hingga tahun 2017 berada pada rata-rata 5,13\%, sehingga potensi pasar asuransi syariah masih sangat terbuka.

Market Share Kontribusi/Premi Asuransi Syariah Dan Asuransi Konvensional Tahun 2012-2017

\begin{tabular}{|c|c|c|c|c|c|c|}
\hline \multirow[t]{2}{*}{ Keterangan } & \multicolumn{6}{|c|}{ Kontribusi/Premi Bruto } \\
\hline & 2012 & 2013 & 2014 & 2015 & 2016 & 2017 \\
\hline \multicolumn{7}{|l|}{ SYARIAH } \\
\hline Life syariah & 5.2 & 7.19 & 8.39 & 8.27 & 9.44 & 11.3 \\
\hline Non Life syariah & 1.82 & 1.61 & 1.61 & 1.96 & 2.87 & 1.8 \\
\hline Total Life + NonLife & 6.95 & 9 & 10 & 10.23 & 12.29 & 12.29 \\
\hline \multicolumn{7}{|l|}{ INDUSTRI } \\
\hline Life & 107.94 & 113.22 & 112.88 & 135.13 & 167.17 & 183.8 \\
\hline Non Life & 39.11 & 46.37 & 54.7 & 60.25 & 66.61 & 59.6 \\
\hline Total Life + NonLife & 147.05 & 159.59 & 167.58 & 195.38 & 233.78 & 243.4 \\
\hline Life Syariah vs Industri & $4.82 \%$ & $6.35 \%$ & $7.43 \%$ & $6.12 \%$ & $5.65 \%$ & $6.15 \%$ \\
\hline Non Life Syariah vs Industri & $4.65 \%$ & $3.47 \%$ & $2.94 \%$ & $3.25 \%$ & $4.31 \%$ & $3.02 \%$ \\
\hline Syariah vs Industri (excl sosial \& & $473 \%$ & $5640 \%$ & 5070 & $524 \%$ & $526 \%$ & $\begin{array}{r}5.05 \\
0 \%\end{array}$ \\
\hline
\end{tabular}

Sumber: Publikasi Statistik Otoritas Jasa Keuangan

Grafik Market Share Tahun 2012-2017

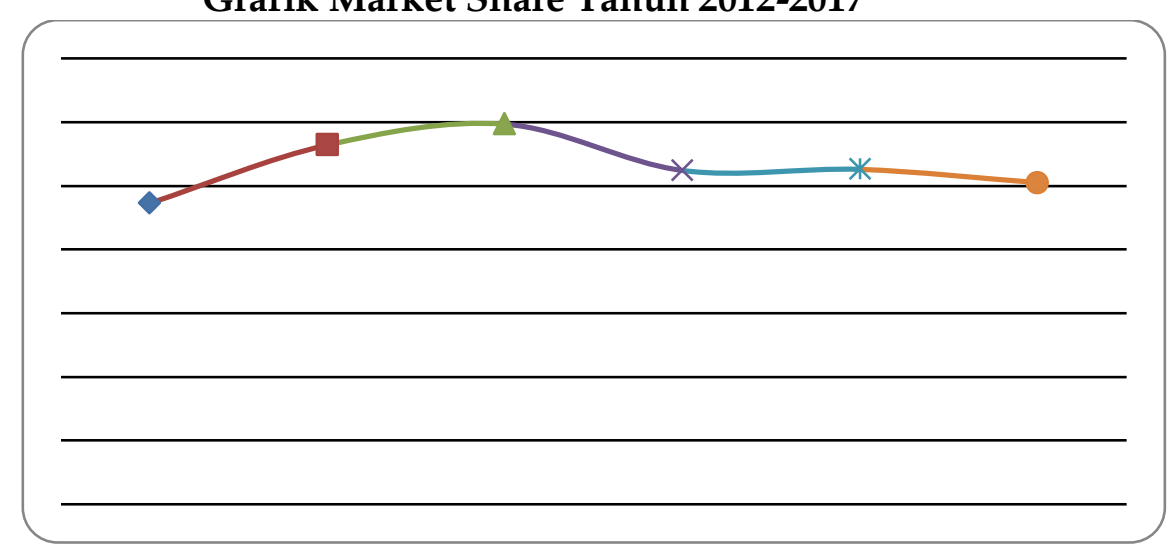

Sumber: Publikasi Statistik Otoritas Jasa Keuangan

${ }^{1}$ https:/ / www.bps.go.id/QuickMap?id=0000000000 
Berdasarkan data-data tersebut, diketahui bahwa pada tahun 2012 hingga tahun 2014, market share kontribusi asuransi syariah terhadap premi asuransi konvensional mengalami kenaikan setiap tahunnya, yakni sebesar 19.3\% untuk tahun 2012 ke 2013 dan kenaikan sebesar 5.80\% untuk tahun 2013 ke 2014, kemudian pada tahun 2015 terjadi penurunan market share sebesar $12.3 \%$ dan peningkatan kembali pada tahun 2016 sebesar $0.4 \%$ dan pada tahun 2017 mengalami penurunan market share sebesar $4 \%$.

Meskipun market share asuransi syariah terbilang rendah, namun jumlah pelaku industri asuransi syariah dari tahun ke tahun mengalami penambahan, tahun 2015 jumlah perusahaan asuransi sebanyak 8 dengan status full syariah dan 47 adalah unit usaha syariah (windows), pada tahun 2016 perusahaan full syariah bertambah masing-masing 1 perusahaan asuransi jiwa, asuransi umum dan hasil spin off perusahaan reasuransi, tahun 2017 masing-masing perusahaan asuransi jiwa dan umum bertambah 1 untuk status full syariah dan 2 unit usaha asuransi jiwa syariah serta penambahan 1 unit usaha asuransi umum syariah.

Jumlah Industri Asuransi Syariah Periode 2015-2017

\begin{tabular}{|l|r|r|r|r|r|r|}
\hline \multirow{2}{*}{ Keterangan } & \multicolumn{2}{|c|}{2015} & \multicolumn{2}{c|}{2016} & \multicolumn{2}{c|}{2017} \\
\cline { 2 - 7 } & Full & Unit & \multicolumn{1}{|c|}{ Full } & Unit & \multicolumn{1}{c|}{ Full } & Unit \\
\hline Asuransi Jiwa Syariah & 5 & 19 & 6 & 21 & 7 & 23 \\
Asuransi Umum Syariah & 3 & 25 & 4 & 24 & 5 & 25 \\
Reasuransi Syariah & - & 3 & 1 & 2 & 1 & 2 \\
\hline Total & 8 & 47 & 11 & 47 & 13 & 50 \\
\hline
\end{tabular}

Sumber: Publikasi Statistik Otoritas Jasa Keuangan

Sejak 23 tahun yang lalu perusahaan asuransi syariah pertama didirikan, market share hanya berada dikisaran 5\% dan faktanya sejak tahun 2015 terus mengalami penurunan, maka dalam makalah ini penulis akan memaparkan faktor-faktor yang merupakan strategi industri asuransi syariah dalam meningkatkan market share-nya pada tahun 2018 dan seterusnya..

\section{METODE PENELITIAN}

Penulis melakukan pengumpulan data dengan cara menelusuri berbagai macam dokumen berupa buku, regulasi dan artikel pada website yang terkait seputar Asuransi Syariah. Hasil penelusuran ditulis dalam bentuk naratif. Studi dokumentasi yang dilakukan penulis seperti pendalaman untuk melakukan kajian dan interpretasi.

\section{HASIL DAN PEMBAHASAN}

\section{Definisi Asuransi dan Asuransi Syariah}

Undang-Undang terbaru No.40 tahun 2014 tentang Perasuransian memberi definisi asuransi sebagai berikut: ${ }^{2}$

Asuransi adalah perjanjian antara dua pihak, yaitu perusahaan asuransi dan pemegang polis yang menjadi dasar bagi penerimaan premi oleh perusahaan asuransi sebagai imbalan untuk:

a. Memberikan penggantian kepada tertanggung atau pemegang polis karena kerugian, kerusakan, biaya yang timbul kehilangan keuntungan, atau tanggung

\footnotetext{
${ }^{2}$ Republik Indonesia, Pemerintah (2014), Undang-undang No. 40 Tahun 2014: Perasuransian.
} 
jawab hukum kepada pihak ketiga yang mungkin diderita tertanggung atau pemegang polis karena terjadinya suatu peristiwa yang tidak pasti, atau

b. Memberikan suatu pembayaran yang didasarkan pada meninggalnya tertanggung atau pembayaran yang didasarkan pada hidupnya tertanggung dengan manfaat yang besarnya telah ditetapkan dan/atau didasarkan pada hasil pengelolaan dana.

Sedangkan definisi Asuransi Syariah ${ }^{3}$ adalah kumpulan perjanjian, yang terdiri atas perjanjian antara perusahaan asuransi syariah dan pemegang polis dan perjanjian di antara para pemegang polis dalam rangka pengelolaan kontribusi berdasarkan prinsip syariah guna saling menolong dan melindungi dengan cara:

a. Memberikan penggantian kepada peserta atau pemegang polis karena kerugian, kerusakan, biaya yang timbul kehilangan keuntungan, atau tanggung jawab hukum kepada pihak ketiga yang mungkin diderita peserta atau pemegang polis karena terjadinya suatu peristiwa yang tidak pasti, atau

b. Memberikan suatu pembayaran yang didasarkan pada meninggalnya peserta atau pembayaran yang didasarkan pada hidupnya peserta dengan manfaat yang besarnya telah ditetapkan dan/atau didasarkan pada hasil pengelolaan dana."

Dengan memperhatikan kedua definisi tersebut, perbedaan antara asuransi syariah dan asuransi konvensional adalah pada tujuan perjanjian dibuat, tujuan perusahaan asuransi konvensional adalah untuk mendapatkan premi, sedangkan perusahaan asuransi syariah bertujuan untuk mengelola kontribusi berdasarkan prinsip syariah guna saling menolong dan melindungi, jika mengacu pada Fatwa DSN MUI No 21, tujuan hakiki asuransi syariah adalah untuk tujuan ta'awun (tolong menolong) dan tujuan investasi (bisnis). Apabila tujuan ikut asuransi syariah adalah orientasinya semata-mata komersil yaitu untuk investasi (bisnis), maka akadnya menggunakan akad tijarah. Sedangkan Peserta asuransi syariah yang niat dan tujuannya mengharapkan ridho Allah Swt., maka keikutsertaaan dalam asuransi syariah adalah untuk tujuan ta'awun (tolong-menolong), dan karena itu akadnya adalah akad tabarru'.

Pelaksanaan sikap saling tolong-menolong dalam kebajikan dan ketakwaan yang diperintahkan Allah Swt dalam firman-Nya, "Dan tolong-menolonglah lamu dalam (mengerjakan) kebajikan dan takwa, dan jangan tolong menolong dalam berbuat dosa dan pelanggaran." (QS. Al-Maidah,2) merupakan nilai-nilai Islam yang tercermin dalam setiap muslim, namun demikian berdasarkan hasil survei nasional literasi dan inklusi keuangan tahun 2016 yang dikeluarkan oleh Otoritas Jasa Keuangan menyebutkan bahwa indeks literasi keuangan sebesar 29,66\% sedangkan indeks inklusi keuangannya adalah sebanyak $67,82 \%$ namun demikian, khusus untuk lembaga keuangan syariah indeks literasi keuangan syariah hanya sebesar $8,11 \%$ dan indeks inklusi keuangan syariah adalah sebanyak $11,06 \%$.

\section{Perbandingan Tingkat Literasi dan Inklusi Keuangan Konvensional dan Syariah}

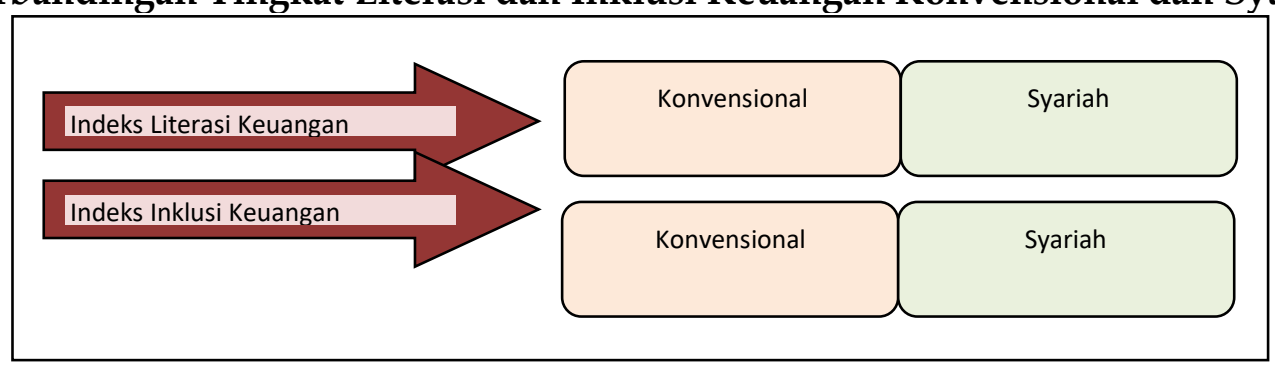

${ }^{3}$ Republik Indonesia, Pemerintah (2014), Undang-undang No. 40 Tahun 2014: Perasuransian. 


\section{Market Share}

Pangsa pasar atau Market Share adalah persentase dari keseluruhan pasar untuk sebuah kategori produk atau servis yang telah dipilih dan dikuasai oleh satu atau lebih produk atau servis tertentu yang dikeluarkan sebuah perusahaan dalam kategori yang sama ${ }^{4}$. Dalam pengertian yang lebih sempit Market share adalah perbandingan volume penjualan industri baik dalam unit maupun dalam rupiah. Jadi pangsa pasar atau market share adalah keseluruhan pasar yang berhasil dikuasai oleh perusahaan untuk menjual produk yang ditawarkan. Oleh karena itu, kegiatan perusahaan yang dilaksanakan untuk meningkatkan market share harus diarahkan kepada langganan guna menarik dan mendorong mereka melakukan pembelian serta kepada calon konsumen dan pelanggan yang sudah ada, agar mereka tidak beralih ke produk lain.

Faktor-faktor permintaan pasar dan pengaruh-pengaruh terhadap market share. Perusahaan yang menaikkan pangsa pasar (market share) mempunyai manfaat sebagai berikut 5 :

1. Perusahaan yang meningkatkan kualitas produk mereka relatif terhadap pesaing menikmati kenaikan pangsa pasar yang lebih besar dari pada mereka yang tingkat kualitasnya tetap atau menurun.

2. Perusahaan yang meningkatkan pengeluaran pemasaran lebih cepat dari tingkat pertumbuhan pasar umumnya mencapai kenaikan pangsa pasar.

3. Perusahaan yang memotong harga mereka jauh lebih besar dari para pesaing tidak mencapai kenaikan pangsa pasar yang berarti.

4. Kebijaksanaan pemasaran harus dapat menentukan gambaran yang jelas dan terarah tentang apa yang akan dilakukan oleh perusahaan di dalam menggunakan setiap kesempatan atau peluang-peluang yang ada pada beberapa pasar sebagai sasaran penjualan

Kegiatan perusahaan yang dilaksanakan untuk meningkatkan market share harus diarahkan kepada langganan guna menarik dan mendorong mereka melakukan pembelian serta kepada calon konsumen dan pelanggan yang sudah ada, agar mereka tidak beralih ke produk lain. Oleh karena itu, dibutuhkan taktik utama dalam mendukung strategi yang digunakan untuk menguasai pangsa pasar dari sebuah kategori. ${ }^{6}$ Taktik utama tersebut adalah diferensiasi, marketing mix, dan selling. Sedangkan kekuatan pemasaran sebuah perusahaan dipengaruhi oleh lingkungan pemasaran, lingkungan tersebut adalah: ${ }^{7}$

1. Lingkungan Pemasaran Internal: bauran pemasaran, target pasar, saluran pemasaran, kepemilikan perusahaan, ukuran perusahaan dan sumber daya.

2. Lingkungan Pemasaran Eksternal: lingkungan ekonomi, sosial, teknologi, tingkat persaingan dan regulasi pemerintah

\section{Bauran Pemasaran Asuransi Syariah}

1. Produk Asuransi Syariah

Berdasarkan Peraturan OJK nomor 23/POJK.05/2015 produk asuransi yang dipasarkan oleh asuransi umum adalah:

a. Program yang dapat diasuransikan yang timbul dari suatu peristiwa yang tidak pasti dengan memberikan penggantian kepada pemegang polis, tertanggung, atau peserta karena kerugian, kerusakan, biaya yang timbul, kehilangan keuntungan, atau tanggung jawab hukum kepada pihak ketiga

4 Thorik Gunara, Marketing Muhammad"Strategi Andal dan Jitu Praktik Bisnis Nabi Muhammad SAW" (Bandung: Masania Prima, 2007), 31.

5 Philip Kotler dan Kevin Lane Keller, Manajemen Pemasaran Edisi Ketiga Belas Jilid 1 (Jakarta: Erlangga, 2008), 332

6 Thorik Gunara, Marketing Muhammad"Strategi Andal dan Jitu Praktik Bisnis Nabi Muhammad saw”(Bandung: Masania Prima, 2007), 32.

7 Miriam A Orsina, FLMI, PCS, ARA, PAHM dan Gene Stone, FLMI, ACS, CLU, Insurance Company Operation, second edition LOMA, 2005), 111 
yang mungkin diderita pemegang polis, tertanggung, atau peserta, atau pemberian jaminan pemenuhan kewajiban pihak yang dijamin kepada pihak yang lain apabila pihak yang dijamin tersebut tidak dapat memenuhi kewajibannya;

b. Program yang menjanjikan perlindungan terhadap 1 (satu) jenis atau lebih risiko yang terkait dengan keadaan kesehatan fisik seseorang atau menurunnya kondisi kesehatan seseorang yang dipertanggungkan

c. Program yang menjanjikan perlindungan terhadap 1 (satu) jenis atau lebih risiko dengan memberikan penggantian atau pembayaran kepada pemegang polis, tertanggung, atau peserta atau pihak lain yang berhak dalam hal terjadi kecelakaan

Lini Usaha untuk Asuransi Umum (Non Life) berdasarkan lampiran SE OJK nomor 13.SEOJK.05/2016 adalah Harta Benda, Kendaraan Bermotor, Pengangkutan, Rangka Kapal, Rangka Pesawat, Satelit, Energi Offshore, Energi Onshore, Rekayasa, Tanggung Gugat, Kecelakaan Diri, Kesehatan, Kredit, Suretyship, Aneka Lainnya

Sedangkan produk asuransi yang dipasarkan oleh asuransi jiwa berdasarkan peraturan OJK nomor 23/POJK.05/2015 adalah:

a. Program yang menjanjikan perlindungan terhadap 1 (satu) jenis atau lebih risiko yang terkait dengan meninggalnya seseorang yang dipertanggungkan, hidup dan meninggalnya seseorang yang dipertanggungkan, atau anuitas asuransi jiwa;Program yang menjanjikan perlindungan terhadap 1 (satu) jenis atau lebih risiko yang terkait dengan keadaan kesehatan fisik seseorang atau menurunnya kondisi kesehatan seseorang yang dipertanggungkan

b. Program yang menjanjikan perlindungan terhadap 1 (satu) jenis atau lebih risiko dengan memberikan penggantian atau pembayaran kepada pemegang polis, tertanggung, atau peserta atau pihak lain yang berhak dalam hal terjadi kecelakaan

Lini Usaha untuk Asuransi Umum (Non Life) berdasarkan lampiran SE OJK nomor 13.SEOJK.05/2016 adalah Kecelakaan Diri. Kesehatan. Ekawarsa. Kematian Berjangka. Dwiguna. Dwiguna Kombinasi. Seumur Hidup. Seumur Hidup Kombinasi. Anuitas Umum. Anuitas Dana Pensiun, Produk Asuransi Yang Dikaitkan Investasi (PAYDI)

2. Price (Ujroh) Asuransi Syariah

Penelitian tentang penentuan selang ujroh yang optimal pada produk asuransi jiwa syariah yang dilakukan oleh PT. LAPI ITB yang bekerjasama dengan, Industri Asuransi Syariah dan OJK menyimpulkan bahwa jika ujroh terlalu besar, maka semua biaya terkait pengelolaan dana tabungan dan dana tabarru' semuanya terbayarkan, kontribusi yang harus dibayarkan oleh peserta menjadi mahal, akibatnya produk asuransi yang ditawarkan akan dirasakan mahal oleh calon peserta asuransi. Sebaliknya jika ujroh yang ditawarkan terlalu kecil maka produk asuransi yang ditawarkan mungkin akan menarik banyak calon peserta, namun dikhawatirkan biaya ini tidak dapat menutup semua biaya yang harus dikeluarkan oleh perusahaan asuransi, akibatnya dalam jangka panjang akan merugikan perusahaan asuransi. 
Grafik Ujroh Optimum Yang Ditawarkan Berdasarkan Tingkat Penjualan Polis Asuransi Syariah

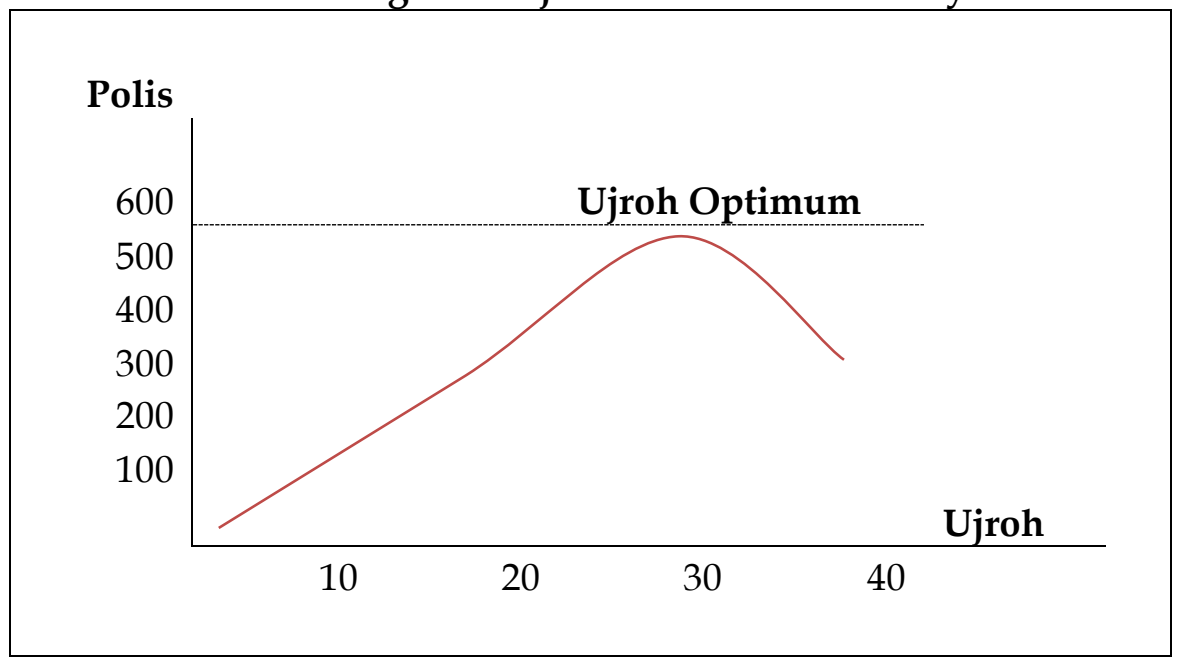

Sumber: Hasil Penelitian PT. LAPITB dan Otoritas Jasa Keuangan

3. Promosi Asuransi Syariah

Promosi adalah kegiatan yang dilakukan oleh perusahaan dalam mempengaruhi nasabah atau calon nasabah untuk membeli yang bisa dilakukan dengan cara komunikasi langsung maupun melalui media iklan ${ }^{8}$.

4. Place (Distribusi) Asuransi Syariah

Sesuai dengan POJK nomor 23/POJK.05/2015 Perusahaan asuransi syariah hanya dapat menggunakan distribusi melalui:

a. Secara langsung (direct marketing);

Saat ini saluran pemasaran yang menggunakan saluran secara langsung dapat menggunakan media masa, media elektronik dan menggunakan media jarak jauh, namun khusus PAYDI wajib diikuti dengan pertemuan tatap muka.

Salah satu alternative saluran distribusi produk asuransi syariah adalah dengan menggunakan distribusi secara langsung, saat ini e-commerce yang dibangun oleh perusahaan-perusahaan start up masih menjadi primadona dalam era milenial saat ini, sudah sepatutnya perusahaan asuransi syariah memanfaatkan kerjasama atau membangun sendiri e-commerce nya dalam upaya meningkatkan market share nya.

b. agen asuransi;

Perusahaan yang memasarkan Produk Asuransi melalui agen asuransi, wajib memastikan bahwa agen asuransi tersebut memenuhi ketentuan peraturan perundang-undangan mengenai agen asuransi.

Isu utama yang sedang hangat menjelang batas waktu spin off seluruh unit usaha syariah adalah pro-kontra dualisme agen windows, dimana status double agent antara agen konvensional dan syariah sempat ramai dibicarakan, namun demikian OJK telah memberikan relaksasi mengenai ketentuan double agent, yakni dengan memperbolehkan adanya agent yang terdaftar pada dua perusahaan asuransi syariah dan konvensional sepanjang kedua perusahaan tersebut adalah sister company. Kabar yang telah disampaikan langsung oleh pejabat OJK pada acara seminar spin off ini memberikan peluang akan meningkatnya market share pada tahun-tahun mendatang, khususnya pada saat batas waktu spin off dilaksanakan.

\footnotetext{
${ }^{8}$ Miriam A Orsina, FLMI, PCS, ARA, PAHM dan Gene Stone, FLMI, ACS, CLU, Insurance Company Operation, second edition LOMA, 2005), 102
} 


\section{c. Bancassurance;}

Perusahaan yang memasarkan Produk Asuransi melalui Bancassurance harus terlebih dahulu memperoleh surat persetujuan Bancassurance dari OJK.

Berdasarkan peraturan perbankan nomor 36/SEOJK.03.2015 tentang Produk dan Aktivitas Bank Umum Syariah dan Unit Usaha Syariah disebutkan bahwa aktivitas kegiatan Bank Umum diklasifikasikan berdasarkan Bank Umum Kegiatan Usaha (BUKU) dimana klasifikasi bank umum yang diperkenankan untuk kerjasama bancassurance adalah untuk kelas BUKU 2. Bagi perusahaan asuransi syariah yang terafiliasi dengan bank syariah maupun telah bekerjasma dengan bank syariah, regulasi ini bisa dimanfaatkan untuk menambah market share kontribusi perusahaannya.

d. badan usaha selain bank.

Perusahaan yang memasarkan Produk Asuransi melalui badan usaha selain bank dengan kriteria tertentu harus terlebih dahulu memperoleh surat persetujuan dari OJK.

\section{Bauran Pemasaran, Manajemen Risiko Dan Underwriting Asuransi Jiwa}

Setiap Bauran Pemasaran yang telah dijelaskan tersebut, memiliki risiko masing-masing, setiap strategi diperlukan manajemen risiko yang tertata untuk mengantisipasi kegagalan dalam penerapannya.

Bagi Ibnu Khaldun manajemen risiko hanya digambarkan dari praktek-praktek yang dilakukan sebagai ekspresi profesionalisme, prinsip kehati-hatian bidang kerja tertentu dalam mencegah atau mengantisipasi risiko, diantara profesi-profesi serta praktek manajemen risikonya adalah:

a. Keahlian Arsitektur dibutuhkan untuk mengetahui, perhitungan dan proses pembangunan rumah dan tempat tinggal untuk melindungi diri sekaligus tempat berteduh manusia, mereka merasa khawatir akan terjadinya permusuhan antar kelompok, diantara cara untuk mengantisipasi rasa kekhawatirannya tersebut adalah mereka berinisiatif menjaga keamanan dan mempertahankan komunitas mereka dengan membangun parit-parit dan membangun pagar-pagar yang melindungi dan mengelilingi mereka. ${ }^{9}$

b. Profesi Pertukangan, profesi pertukangan dibutuhkan karena merupakan keahlian penting untuk mengolah kayu dan menjadikan bahan bakar bagi kehidupan mereka, sebagai tongkat untuk bersandar dan perlindungan atau pembelaan diri, sebagai tiang penyangga bagi bangunan ataupun segala sesuatu yang dikhawatirkan condong dan runtuh, serta berbagai kegunaan lainnya. ${ }^{10}$

c. Profesi Kebidanan, keahlian kebidanan ini adalah sebagai upaya mengeluarkan janin manusia dari perut ibunya dengan penuh kehati-hatian dari rahim, menyiapkan faktor-faktor yang membantu mempercepat persalinan. ${ }^{11}$

Berdasarkan kajian teori yang menjadi rujukan industri asuransi di Indonesia, peneliti merangkum dari 4 penulis buku, 3 penulis buku asuransi konvensional dan 1 dari penulis asuransi syariah, pencarian variabel underwriting, baik asuransi syariah maupun konvensional masih menggunakan rujukan buku asuransi konvensional dan selama hal ini tidak bertentangan dengan prinsip syariah.

\footnotetext{
${ }^{9}$ Khaldun, Muhammad, Al Allamah Abdurrahman, (2001), Mukaddimah Ibnu Khaldun, Penerjemah Irham, Masturi dll (2011), Jakarta: Pustaka Al Kautsar, hal. 746

${ }^{10} \mathrm{Ibid}$, hal. 748

11 Ibid, hal. 754
} 
Tabel 2

Matrik Faktor Risiko Dari Kajian Teori

\begin{tabular}{|c|c|c|c|c|}
\hline \multirow{2}{*}{ Faktor Risiko } & \multicolumn{4}{|c|}{ Kajian Teori No: } \\
\hline & 1 & 2 & 3 & 4 \\
\hline 1. Alasan Membentuk Kelompok & A & - & A & A \\
\hline 2. Jenis Kelompok & $\mathrm{H}$ & - & A & $\mathrm{B}$ \\
\hline 3. $\quad$ Ukuran Kelompok & $G$ & - & $\mathrm{B}$ & $\mathrm{C}$ \\
\hline 4. $\quad$ Tingkat Turnover Keanggotaan & $\mathrm{J}$ & - & $C \& D$ & $\mathrm{D}$ \\
\hline 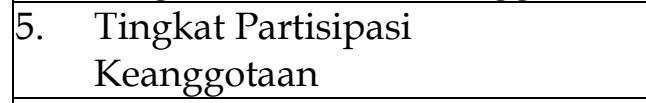 & $\mathrm{L}$ & - & $\mathrm{E}$ & $\mathrm{E}$ \\
\hline 6. $\quad$ Lokasi Geografis & $\mathrm{I}$ & - & - & $\mathrm{F}$ \\
\hline 7. Jenis Bisnis (Nature of Bisnis) & $\mathrm{H}$ & $\mathrm{E}$ & $\mathrm{G}$ & $\mathrm{G}$ \\
\hline 8. $\quad$ Kelas Jabatan Pekerja & $\mathrm{C}$ & - & $\mathrm{F}$ & $\mathrm{H}$ \\
\hline 9. $\quad$ Distribusi Usia & K & A & - & $\mathrm{I}$ \\
\hline 10. Distribusi Jenis Kelamin & K & B & - & $\mathrm{J}$ \\
\hline 11. Perkiraan Persistensi & $\mathrm{N}$ & $\mathrm{D}$ & - & K \\
\hline 12. Jumlah Pertanggungan & A & - & $\mathrm{F}$ & $\mathrm{L}$ \\
\hline 13. Pengalaman Klaim Sebelumnya & $\mathrm{O}$ & - & - & $\mathrm{L}$ \\
\hline 14. Jenis Asuransi & A & - & - & $\mathrm{M}$ \\
\hline 15. Persyaratan Eligibility Pekerja & $\mathrm{B}$ & - & - & $\mathrm{N}$ \\
\hline $\begin{array}{l}\text { 16. } \begin{array}{l}\text { Tingkat Pengelompokan } \\
\text { Manfaat }\end{array} \\
\end{array}$ & $\mathrm{M}$ & - & $\mathrm{F}$ & $\mathrm{O}$ \\
\hline 17. Jenis Administrasi & $\mathrm{D}$ & - & - & $\mathrm{p}$ \\
\hline 18. Jenis dan Jumlah Komisi & $\mathrm{E}$ & - & - & $\mathrm{Q}$ \\
\hline 19. Aspek Medis & - & $\mathrm{C}$ & - & - \\
\hline
\end{tabular}

a. Usia Peserta Masuk Asuransi

Pandangan Islam berdasarkan hadis Rasulullah Saw mengenai umur maksimal umat manusia adalah antara 60 tahun sampai dengan 70 tahun

Diriwayatkan oleh Abu Hurairah r.a, katanya: Rasulullah saw telah bersabda: Umur umatku diantara 60 ke 70 tahun, dan tidak ramai yang melebihi daripada itu Riwayat Imam Tirmizi.

Hadis lainnya tentang usia 60 tahun adalah:12

Dari Abu Hurairah, Rasulullah Saw berkata, Allah Swt telah memberi kesempatan kepada seseorang yang dipanjangkan usianya sampai 60 tahun.

Selanjutnya didalam al Qur'an surat al ahqaaf memberi petunjuk bahwa manusia mengalami masa keemasannya atau matang pada usia 40 tahun.

....Mengandungnya sampai menyapihnya adalah tiga puluh bulan, sehingga apabila Dia telah dewasa dan umurnya sampai empat puluh tahun ia berdoa: "Ya Tuhanku, tunjukilah aku untuk mensyukuri nikmat Engkau yang telah Engkau berikan kepadaku dan kepada ibu bapakku dan supaya aku dapat berbuat amal yang saleh yang Engkau ridhai; berilah kebaikan kepadaku dengan (memberi kebaikan) kepada anak cucuku. Sesungguhnya aku bertaubat kepada Engkau dan Sesungguhnya aku Termasuk orangorang yang berserah diri". (Al Ahqaaf:15)

Menurut imam Sayyid Quthb dalam kitab tafsir fi zihlail Qur'an dijelaskan bahwa kehidupan pertama manusia dimulai dengan perawatan orang tuanya, dan perilakunya terus berlanjut hingga mencapai usia dewasa dan berkemampuan untuk mengambil risiko dan memilih, kedewasaan dicapai pada

${ }^{12}$ Terjemah Nawawi, Imam Abu Zakaria Yahya bin Syaraf, Riyadhus Shalihin, Jilid 1, Penerjemah Sunarto, Achmad (1999), Jakarta: Pustaka Amani. hal. 187 
usia sekitar 30 hingga 40 tahun. Usia 40 tahun merupakan puncak kematangan dan kedewasaan. Pada usia ini sempurnalah segala potensi dan kekuatan, sehingga manusia memiliki kesiapan untuk merenung dan berpikir secara tenang dan sempurna. Fitrah yang lurus lagi sehat mengacu pada apa yang ada dibalik kehidupan dan sesudahnya, mulai merenungkan tempat kembali dan akhirat. ${ }^{13}$

Kesimpulan yang dapat ditarik berdasarkan teori yang sudah ada (konvensional) al qur'an dan kajian tafsirnya serta hadis Rasulullah tersebut adalah:

1. Semakin tua usia peserta maka risiko lebih tinggi dibandingkan usia muda

2. Usia maksimal peserta asuransi syariah adalah 60 - 70 tahun, dan yang menarik adalah jika dilakukan survey terhadap perusahaan asuransi jiwa, rata-rata ketentuan maksimal usia masuk asuransi adalah 65 tahun

3. Terdapat jarak usia yang tingkat kematangan fisik manusia mengalami puncaknya, yaitu usia 30 - 40 tahun, sehingga secara teknis asuransi, usia tersebut risikonya lebih rendah dan preminya relative lebih rendah,

Penetapan Premi Asuransi Syariah: ${ }^{14}$

1. Pembayaran premi didasarkan atas jenis akad tijarah dan jenis akad tabarru'.

2. Untuk menentukan besarnya premi perusahaan asuransi syariah dapat menggunakan rujukan, misalnya tabel mortalita untuk asuransi jiwa dan tabel morbidita untuk asuransi kesehatan,dengan syarat tidak memasukkan unsur riba dalam penghitungannya.

3. Premi yang berasal dari jenis akad mudharabah dapat diinvestasikan dan hasil investasinya dibagi-hasilkan kepada peserta.

4. Premi yang berasal dari jenis akad tabarru' dapat diinvestasikan.

b. Kegiatan Sehari-hari

Kesamaan kegiatan yang diatur didalam persyaratan menjadi anggota Kelompok, baik itu kesamaan jenis pekerjaan, seperti kesamaan kegiatan, berdasarkan lokasi, kesamaan keanggotaan dalam berkelompok memiliki tingkat risiko yang berbeda-beda, kepentingan yang sama, yang dimiliki oleh anggota kelompok, diduga sebagai alat ukur kesamaan risiko, dimana Ibnu Khaldun mengatakan "perbedaan hal ihwal penduduk adalah akibat dari perbedaan cara mereka memperoleh kehidupan"15, hal ihwal yang dimaksud, dijelaskan secara terpisah dalam bukunya tersebut adalah seperti perbedaan gaya hidup, pola makan dan kegiatan harian yang pada akhirnya akan mempengaruhi tingkat kesehatan penduduk tersebut.

c. Pengalaman dan Survei Kependudukan

Dalam menjalankan fungsi sosial layaknya jaminan sosial atau dana pensiun pernah dilakukan dimasa Umar Ibnu Khathab ra. Praktek jaminan sosial yang dilakukan oleh Umar ra, memiliki prosedur standar yang dapat diterapkan pula pada asuransi syariah, prosedur tersebut adalah dengan melalui proses sensus (pendataan) dan berdasarkan data statistik tersebut Umar ra menghitung antara total penerimaan dan perkiraan jumlah uang keluar yang akan diberikan berdasarkan skala prioritas tertentu. Fakta sejarah ini mencatat bahwa kegiatan

${ }^{13}$ Quthb, Syahid Sayyid (1992), Fizhilalil Qur'an, Beirut: Darusy-Syuruq, Penerjemah Yasin, As'ad dll (2000), Jakarta: Gema Insani Press hal. 322

${ }^{14}$ Dewan Syariah Nasional Majelis Ulama Indonesia (2001), Fatwa No.21/DSN-MUI/X/2001, Tentang Pedoman Umum Asuransi Syariah

${ }^{15}$ Khaldun, Muhammad, Al Allamah Abdurrahman, (2001), Mukaddimah Ibnu Khaldun, Penerjemah Irham, Masturi dll (2011), Jakarta: Pustaka Al Kautsar, hal. 174 
sensus yang dilakukan Umar ra ini adalah sensus yang pertama kali terjadi di dunia 16

d. Letak Geografis

Letak Geografis tentu mempengaruhi budaya, pola hidup, lingkungan dan pola makan, menurut Ibnu Khaldun: Kedokteran dibutuhkan dimasyarakat kota dan berperadaban, bukan masyarakat badui ${ }^{17}$ letak geografis juga dapat menilai seberapa besar peran pemerintah dalam menjalankan kebijakan publik tentang pembangunan adapun menurut Ibnu Khaldun kebijakan pembangunan harus mempunyai strategi agar teratur, keputusan hukum di lingkungan mereka itu kadang bersandarkan kepada syariat yang diturunkan Allah dimana keyakinan mereka akan pahala dan siksa yang diinformasikan oleh mubalighnya, kadang bersandarkan siasat akal, dimana harapan untuk mendapatkan balasan, seetelah dia mengetahui kemaslahatan-kemaslahatan mereka, manfaatnya terdapat di dunia dan akhirat, karena syar'i (pembuatan syariat), Allah maha mengetahui kemaslahatan-kamaslahatan akhir demi menjaga keselamatan para hamba di akhirat, sehingga membuat mereka patuh kepadanya ${ }^{18}$. Seperti pernyataan Ibnu khaldun bahwa penyakit lebih banyak menjangkiti masyarakat kota dan berperadaban dibandingkan masyarakat badui karena faktor-faktor sebagai berikut:

a. Tingkat kemakmuran dan banyaknya variasi makanan, mereka jarang mengkonsumsi satu jenis makanan saja, seringkali memasak lebih dari empat puluh jenis makanan, seperti sayur, buah, rempah baik yang kering maupun dimasak, berbeda dengan masyarakat badui yang jarang berkonsumsi berlebihan atau secara sederhana bahkan banyak kebiasaan mereka yang kelaparan.

b. Kondisi udara di kota banyak tercemar dan berpolusi karena bercampur dengan uap-uap dari sisa makanan yang membusuk. Udara yang baik dan sehat sangat efektif dalam menyegarkan jiwa dan memperkuat aktivitasnya. Sedangkan masyarakat badui kondisi udara dalam komunitas mereka relatif dari bebas polusi.

c. Olahraga tidak banyak dilakukan oleh masyarakat kota dan peradaban, mereka lebih banyak berdiam diri, di rumah, tidak perduli dengan olah raga, akibatnya berbagai penyakit lebih banyak. Hal ini tidak terjadi dengan masyarakat badui yang karena profesinya sebagai peternak, mereka sering melakukan aktifivitas, bergerak, berburu, berkuda, mencari makan dan aktivitas-aktivitas fisik lainnya

e. Masa Perjanjian Asuransi

Sudah menjadi kewajiban setiap orang yang berkontrak bisnis, bahwa dalam membuat perjanjian asuransi hendaklah ditetapkan batas waktu pembayarannya, hak klaim dan kewajiban-kewajiban kontrak lainnya, baik dalam bentuk ketentuan umum maupun ketentuan khusus, untuk dapat memahami bagaimana para sahabat mengatur syarat-syarat pelaksanaan kontrak, berikut ini adalah sepenggal catatan sejarah mengenai standar batasan waktu untuk berkontrak;

Umar Ibn Khathab Ra pernah membuat standar pelaksanaan kerja dan mengawasinya, diriwayatkan bahwa Umar membebani beberapa pegawainya dengan beberapa pekerjaan dan menentukan batasan waktunya yang sempit

${ }^{16}$ Hitti, Philip K (2002), History of The Arabs, Palgrave Macmillan, New York, Penerjemah Yasin, Cecep Lukman \& Dedi Slamet Riyadi (2013), Jakarta: Serambi., Hal.214

17 Ibid, hal. 763

18 Ibid hal. 542 
untuk menyelesaiakannya dan menghubungkan gaji dengan penyelesaian pekerjaan. Surat Umar kepada Abu Musa Al-Asya'ari Sesungguhnya aku telah mengirimkan kepadamu untuk begini dan begini, maka berilah ia dua ratus durham. Dan apabila dia datang lagi setelah itu, maka jangan memberinya lagi apapun. ${ }^{19}$

f. Gaya Hidup Sehat

Mengkonsumsi alkohol atau obat terlarang, berdasarkan penelitian kedokteran akan memberikan efek tidak normal atas fungsi organ-organ tubuh, seperti liver, jantung dan otak.Kisah seorang pemuda yang diancam dan terpaksa harus memilih satu diantara dihadapkan pada tiga pilihan. yaitu berzina, membunuh anak dan minum keras, pemuda tersebut memilih minuman keras sampai mabuk, dalam kondisi tidak sadar, justru pemuda tersebut melakukan perbuatan berzina dan membunuh anak kecil.20 Kesimpulannya dari kisah ini adalah minuman ber alkohol sangat berbahaya atau memiliki risiko yang tinggi terhadap dirinya dan orang lain, sehingga apabila diketahui bahwa calon peserta mengajukan dengan isian SPPA nasabah tersebut mengakui pernah minum minuman keras (ber alkohol) akan mempengaruhi keputusan underwriting lebih berisiko tinggi dan status label Haram sudah mutlak ditinggalkan oleh perusahaan asuransi jiwa syariah

Selain itu nilai-nilai kejujuran juga menjadi nilai penting dalam pengisian formulir asuransi syariah, dalam kitab Tanbihul Ghafilin disebutkan bahwa nabi Saw bersabda: Hendaknya kamu selalu jujur, karena kejujuran itu membimbing kepada kebaikan dan kebaikan itu membimbing ke surga. Seseorang yang selalu berkata benar dan membiasakan mengatakan kebenaran dicatat di sisi Allah sebagai orang yang benar, jauhilah olehmu dusta, karena dusta itu mengajak kepada kejahatan dan kejahatan itu mengajak ke neraka. ${ }^{21}$

Kajian klasik dalam kitab Tanbihul Ghafilin atas konsep jujur atau itikad baik diatas, memberikan gambaran bahwa, dusta atau pendusta wajib dijauhi, sebab keduanya lebih dekat kepada kejahatan, entah kejahatan moral (moral hazard) maupun kejahatan saat klaim nantinya, pelanggaran atas prinsip itikad baik ini dapat mengakibatkan pertanggungan menjadi batal atau batal sejak awal dan atau dilakukan perbaikan dengan kondisi yang berbeda, pelanggaran dapat terjadi karena beberapa hal misalnya: ${ }^{22}$

1. Tidak mengungkapkan informasi secara benar dan lengkap

2. Menyembunyikan informasi

3. Informasi yang diungkapkan keliru, atau dengan sengaja memberikan informasi yang tidak benar.

\section{KESIMPULAN}

Faktor-faktor underwriting seperti usia, letak geografis, kegiatan sehari-hari, pengalaman dan survey kependudukan, masa perjanjian asuransi dan gaya hidup sehat merupakan faktor penting yang perlu diperhatikan oleh perusahaan asuransi jiwa

19 Ahmad Al Haritsi, Jaribah (2003), Al Fiqh Al Iqhtishadi Li Amiril Mukminiin Umar Ibnu Al Khathab, Jeddah: Dar Al Andalus Al Khadra, Penerjemah: Zamakhsyari, Asmuni Solihan, Fikih Ekonomi Umar Bin Khathab, Kalifa.hal. 700

${ }^{20}$ Samarqandhi, Al Faqih Abu Laits, Tanbihul Ghafilin (983), Penerjemah, Juhaidah, Abu (1999) Tanbihul Ghafilin, Nasihat Bagi Yang lalai, Pustaka Amani.hal. 172

21 ibid, hal. 269

${ }^{22}$ Iskandar, Kasir dll (2002), Dasar-dasar Asuransi Jiwa, Kesehatan dan Anuitas, AAMAI.

hal. 60 
dalam memitigasi risiko yang dihadapi dalam mengembangkan strategi untuk mengembangkan bauran pemasaran.

Industri asuransi syariah bisa menjadikan kitab klasik Islam sebagai acuan dalam mengembangkan teknik dan operasional asuransi syariah, terbukti ketika penulis melakukan eksplorasi terhadap kitab-kitab klasik Islam menemukan teori-teori faktor underwriting yang sebelumnya hanya dibahas secara teori konvensional, dengan adanya bukti-bukti ini maka diharapkan akan memacu para peneliti ekonomi syariah.

\section{DAFTAR PUSTAKA}

Ahmad Al Haritsi, Jaribah (2003), Al Fiqh Al Iqhtishadi Li Amiril Mukminiin Umar Ibnu Al Khathab, Jeddah: Dar Al Andalus Al Khadra, Penerjemah: Zamakhsyari, Asmuni Solihan, Fikih Ekonomi Umar Bin Khathab, Kalifa.

Arif, M. Nur Rianto (2012), Lembaga Keuangan Syariah Suatu Kajian Teoritis Praktis, Bandung: Pustaka Setia.

Bailey, Richard (1987), Underwriting in Life and Health Insurance Companies, LOMA.inc.

Batasa Consulting (2014), Studi Kelayakan Spin Off BRIngin Life Syariah, Studi Kelayakan Untuk BRIngin Life Syariah, Jakarta.

Bickley, Mary C. dll (2007), Life and Health Insurance Underwriting Second Edition, LOMA. Biro Riset Lembaga Management FEUI (2012), Analisis Industri Asuransi Kredit Dan Penjaminan Kredit Untuk UMKM. Jakarta

Departemen Agama RI, Al-Qur'an Tajwid dan Terjemahnya (2002). Bandung: PT. Syaamil Cipta Media.

Dewan Syariah Nasional Majelis Ulama Indonesia (2001), Fatwa No.21/DSNMUI/X/2001, Tentang Pedoman Umum Asuransi Syariah.

Dewan Syariah Nasional Majelis Ulama Indonesia (2002), Fatwa No.39/DSNMUI/X/2002, Tentang Asuransi Haji.

Dewan Syariah Nasional Majelis Ulama Indonesia (2006), Fatwa No.51/DSNMUI/III/2006, Tentang Akad Mudharabah Musytarakah Pada Asuransi Syariah.

Dewan Syariah Nasional Majelis Ulama Indonesia (2006), Fatwa No.52/DSNMUI/III/2006, Tentang Akad Wakalah bil Ujrah Pada Asuransi Syariah.

Dewan Syariah Nasional Majelis Ulama Indonesia (2006), Fatwa No.53/DSNMUI/III/2006, Tentang Akad Tabarru' Pada Asuransi Syariah.

Djojosoedarso. Soeisno (1999), Prinsip Manajemen Risiko dan Asuransi, Jakarta: Salemba Empat.

Hitti, Philip K (2002) , History of The Arabs, Palgrave Macmillan, New York, Penerjemah Yasin, Cecep Lukman \& Dedi Slamet Riyadi (2013), Jakarta: Serambi.

Huda, Nurul \& Mohamad Heykal (2010), Lembaga Keuangan Islam Tinjauan Teoritis dan Praktis, Jakarta: Kencana Prenada Media Group.

Iskandar, Kasir dll (2002), Dasar-dasar Asuransi Jiwa, Kesehatan dan Anuitas, AAMAI.

Jones, Harriet E (2005), Principles of Insurance: Life, Health and Annuities third edition, LOMA.

Khaldun, Muhammad, Al Allamah Abdurrahman, (2001), Mukaddimah Ibnu Khaldun, Penerjemah Irham, Masturi dll (2011), Jakarta: Pustaka Al Kautsar

Menteri Keuangan (2010), Peraturan No. 18/PMK.010 /2010, Tentang Penerapan Prinsip Dasar Penyelenggaraan Asuransi Dan Usaha Reasuransi Dengan Prinsip Syariah.

Menteri Keuangan (2012), Peraturan No. 227/PMK.010/2012, Tentang Perubahan Atas Peraturan Menteri Keuangan No. 18/PMK.010/2010 Tentang Penerapan Prinsip Dasar Penyelenggaraan Asuransi Dan Usaha Reasuransi Dengan Prinsip Syariah.

Menteri Tenaga Kerja dan Transmigrasi (2013), Kepmen nomor 141 Tahun 2013 tanggal 17 April 2013, Penetapan Standar Kompetensi Kerja Nasional Indonesia (SKKNI) Kategori Jasa Keuangan dan Asuransi, Golongan Pokok Asuransi, 
Reasuransi dan Dana Pensiun, Bukan Jaminan Sosial Wajib dan Golongan Pokok Jasa Penunjang Untuk Jasa Keuangan, Asuransi dan Dana Pensiun Lainnya.

Mubarakhfury, Syeikh Shafiyurrahman (1997), Sirah Nabawiyah, Riyadh: Darus-Salam, Penerjemah Suhardi, Kathur (1997), Jakarta: Pustaka Al Kautsar.

Nachrowi, Djalal Nachrowi \& Hardius Usman (2002), Penggunaan Teknik Ekonometrik, Jakarta: PT. Raja Grafindo Persada.

Nannan, Zhang (2007), Underwriting, Investment and Insurance Supply, Empirical Analysis of China Insurance Market, Taiwan APRIA Conference Paper, Insurance School, Central University of Finance \& Economics, China

Nasution, Mustafa Edwin dll (2006), Pengenalan Ekslusif Ekonomi Islam, Jakarta: Kencana.

Nasution, Mustafa Edwin \& Nurul huda dll (2009), Ekonomi Makro Islam, Jakarta: Kencana.

Nasution, Mustafa Edwin \& Hardius Usman, (2007), Proses Penelitian Kuantitatif, Jakarta: Lembaga Penerbit FEUI.

Nawawi, Imam Abu Zakaria Yahya bin Syaraf, Riyadhus Shalihin, Jilid 1, Penerjemah Sunarto, Achmad (1999), Jakarta: Pustaka Amani.

Oschischning, Gerald Krenn Ulrike (2003), Systemic Risk Factors In The Insurance Industry And Methods For Risk Assessment.

Perwataatmaja, Karnaen A. \& Anis Byarwati (2008), Jejak Rekam Ekonomi Islam, Jakarta: Cicero Publishing.

Quthb, Syahid Sayyid (1992), Fizhilalil Qur'an, Beirut: Darusy-Syuruq, Penerjemah Yasin, As'ad dll (2000), Jakarta: Gema Insani Press.

Republik Indonesia, Pemerintah (1992), Undang-undang No. 2 Tahun 1992: Usaha Perasuransian.

Republik Indonesia, Pemerintah (2014), Undang-undang No. 40 Tahun 2014: Perasuransian.

Republik Indonesia, Pemerintah (2013), Undang-undang No. 1 Tahun 2013: Lembaga Keuangan Mikro.

Samarqandhi, Al Faqih Abu Laits, Tanbihul Ghafilin (983), Penerjemah, Juhaidah, Abu (1999) Tanbihul Ghafilin, Nasihat Bagi Yang lalai, Pustaka Amani.

Stone, Gene (2000), Pengoperasian Perusahaan Asuransi, Penerjemah Taufik, Nurmansyah, LOMA Indonesia.

Sula, Muhammad Syakir, (2004), Asuransi Syariah (Life And General): Konsep Dan Operasional, Jakarta: Gema Insani Press.

Fatwa DSN-MUI nomor 21/DSN-MUI/III/2011 tentang Asuransi Syariah Dalam Mekanisme Perdagangan Efek Bersifat Ekuitas Di Pasar Reguler Bursa Efek ditetapkan tanggal 08 Maret 2011

Miriam A Orsina, FLMI, PCS, ARA, PAHM dan Gene Stone, FLMI, ACS, CLU, Insurance Company Operation, second edition LOMA, 2005)

Philip Kotler dan Kevin Lane Keller, Manajemen Pemasaran Edisi Ketiga Belas Jilid 1 (Jakarta: Erlangga, 2008),

Portal https:/ / www.bps.go.id/QuickMap?id=0000000000

Thorik Gunara, Marketing Muhammad“Strategi Andal dan Jitu Praktik Bisnis Nabi Muhammad SAW" (Bandung: Masania Prima, 2007),

Republik Indonesia, Pemerintah (2014), Undang-undang No. 40 Tahun 2014:

Perasuransian. 